\title{
Role of essential lipids in copepod nutrition: no evidence for trophic upgrading of food quality by a marine ciliate
}

\author{
W. C. M. Klein Breteler ${ }^{1, *}$, M. Koski ${ }^{1,2}$, S. Rampen ${ }^{1}$ \\ ${ }^{1}$ Royal Netherlands Institute for Sea Research (NIOZ), PO Box 59, 1790 AB, Den Burg, The Netherlands \\ ${ }^{2}$ Present address: Danish Institute for Fisheries Research, Kavalergården 6, 2920 Charlottenlund, Denmark
}

\begin{abstract}
The ciliate Strombidium sulcatum was used to feed and grow young stages of the copepods Temora longicornis (Müller) and Pseudocalanus elongatus (Boeck). The ciliate was cultured in the laboratory using either bacteria or the green alga Dunaliella sp. as a food source. Young copepodites of both copepod species consumed $S$. sulcatum at significant rates, but after 3 d, weightspecific ingestion decreased more than 2 -fold. Larvae and copepodites feeding on $S$. sulcatum developed at suboptimal rates, survived poorly and showed abnormal morphology in comparison to control individuals fed a good-quality Rhodomonas sp. diet. The specific mass of fatty acids in S. sulcatum was much lower than in the Dunaliella sp. diet. However, the fatty acid composition of the protozoan more or less resembled that of the food, lacking long-chain highly unsaturated fatty acids (HUFAs). Sterols only occurred in Dunaliella sp., although in low abundance of unuseful $\Delta 7$ sterols. Obviously, S. sulcatum did not biochemically enhance bacterial or algal food for subsequent use at higher trophic levels, and only transferred fatty acids without further conversion. The results indicate a deficiency in the ciliate of HUFAs and sterols which are essential nutrients for copepod growth. Apart from energy, ciliates seem to contribute little nutritive value to the diet of higher trophic levels, and this may limit secondary production during periods of low algal abundance.
\end{abstract}

KEY WORDS: Copepods $\cdot$ Ciliates $\cdot$ Grazing $\cdot$ Food quality $\cdot$ Fatty acids $\cdot$ Sterols Resale or republication not permitted without written consent of the publisher

\section{INTRODUCTION}

The biochemical composition of marine microorganisms is well recognised as influencing the productivity of aquatic systems. In particular, the lipids contained in algae and other organisms at the base of the food chain seem to determine the quality of food for the higher trophic levels. In aquatic environments $\omega 3$ polyunsaturated fatty acids (PUFAs) are an essential requirement for most metazoans, but they cannot be synthesised by these animals and must be obtained from algal food. A subset of PUFAs, the long-chain, highly-unsaturated fatty acids (HUFAs) eicosapentaenoic acid (20:5 03 , EPA) and docosahexaenoic acid (22:6 63, DHA) are 'semi-essential' compounds that animals can produce only slowly; hence, HUFAs can enhance zooplankton growth rates when supplied with the food (Brett \& Müller-Navarra 1997 and references therein). Laboratory observations show that copepods also require sterols as an essential component (Ederington et al. 1995, Klein Breteler et al. 1999), which they, like all crustaceans, cannot produce themselves (Dewey 1967, Goad 1981).

For zooplankton, plant material is the major source of HUFAs and sterols (Sargent et al. 1987, Brown et al. 1997). However, copepods also feed on micro- and nanozooplankton, of which the lipid compositions are poorly known (Wood 1988) and the synthesis or bioconversion of HUFAs and sterols is uncertain. Recently, the heterotrophic flagellate Bodo sp. was found to produce EPA and DHA at high rates (Zhukova \& Kharlamenko 1999), and among heterotrophic dinofla- 
gellates a few species are known to produce DHA (Harrington \& Holz 1968, Barclay et al. 1994, Klein Breteler et al. 1999). Sterols are synthesised by some species of amoebae and tryponosomatid protozoans (Volkman 2003), and by the heterotrophic dinoflagellate Oxyrrhis marina (Klein Breteler et al. 1999). Apparently, heterotrophic dinoflagellates have maintained the capability of their autotrophic conspecifics to produce HUFAs and sterols. Since protozoans feed on detritus and pico- and nanoplankton, they may both channel energy and enhance biochemical quality from the microbial food web towards higher trophic levels. Such trophic upgrading has been shown for O. marina. This heterotrophic dinoflagellate transfers the unsuitable Dunaliella sp., containing no HUFAs and hardly any sterols, into high-quality food rich in both essential lipids, which allows fast development of copepods that feed on O. marina (Klein Breteler et al. 1999). Recently, the intermediary dinoflagellate Gyrodinium dominans growing on Phaeocystis globosa has been shown to improve the nutritional quality of $P$. globosa for Acartia tonsa, as indicated by the much higher egg production rate of $A$. tonsa feeding on the dinoflagellate than of those feeding on P. globosa directly (Tang et al. 2001).

In marine ciliates, synthesis of sterols has not been detected, except for cholesterol in the hypotrich Euplotes sp. (class Nassophorea) (Harvey \& McManus 1991). However, Tetrahymena spp. and several scuticociliates (both belonging to the class Oligohymenophora) produce tetrahymanol and hopanoids, which functionally replace sterols when algal sterols are not available (Harvey \& McManus 1991, Harvey et al. 1997). The fatty acid composition of ciliates tends to resemble that of the food they have consumed. Since PUFAs generally do not occur in bacteria (Phillips 1984), they also do not occur in bacterivorous ciliates, except in the rare case when PUFAs are present in the bacteria consumed (Harvey et al. 1997). Ciliates may convert lipids obtained from their food to $\omega 6$-PUFAs (Kaneshiro et al. 1979, Sul \& Erwin 1997). There are also a few indications of $\omega 3$-PUFA and -HUFA production by ciliates, but only in marine species. Thus, linolenic acid, 18:3 $\omega 3$, has been found in the bacterivorous marine scuticociliate Pleuronema sp. (Ederington et al. 1995). The marine scuticociliate Parauronema acutum produces EPA and DHA at low rates, when shorter-chain $\omega 3$-fatty acids (linolenic acid), among others, occur in the medium (Sul \& Erwin 1997); Euplotes crassus does the same, but from bacteria containing only up to $18 \mathrm{C}$ mono-unsaturated fatty acids (Zhukova \& Kharlamenko 1999). Obviously, our present knowledge of the biochemical capability of ciliates is not complete. Due to their significance in the food-chain (Sanders \& Wickham 1993), upgrading of food quality by marine ciliates would stimulate sec- ondary production, particularly under oligotrophic conditions when algae are not abundant.

In this study we used the marine bacteri-/herbivorous oligotrich ciliate Strombidium sulcatum (class Polyhymenophora), to test the hypothesis that lipid compounds essential for copepods can be produced by the ciliate. We fed $S$. sulcatum with bacteria, probably containing neither PUFAs nor sterols, and with the chlorophyte Dunaliella sp., which does contain the es-


sterols. Both bacteria and Dunaliella sp. are known not to support copepod growth alone. To assess any improved food value after trophic transfer to the protozoan, we compared concentrations of fatty acids and sterols in S. sulcatum and in the algal food, and we measured the rate of development and grazing of copepods feeding on S. sulcatum.

\section{MATERIALS AND METHODS}

Using continuous cultures, the ciliate Strombidium sulcatum was grown using either bacteria or the chlorophycean alga Dunaliella sp. as the food source. The ciliate was fed to young stages of the copepods Temora longicornis (Müller) and Pseudocalanus elongatus (Boeck). Development, mortality and grazing rates of the copepods were monitored. The cryptophycean Rhodomonas sp. was used as a control food, allowing good growth and low mortality of the copepods. The fatty acid and sterol composition of algal and protozoan food were measured as described below.

Cultures. Copepods were obtained from brood stocks of Temora longicornis and Pseudocalanus elongatus, which were continuously cultured in the laboratory at $15^{\circ} \mathrm{C}$ with a surplus of food $\left(>300 \mu \mathrm{g} \mathrm{C}^{-1}\right)$. The food consisted of the cryptophyte Rhodomonas sp., the haptophyte Isochrysis galbana and the heterotrophic dinoflagellate Oxyrrhis marina. The algae were cultured in 31 chemostats, using a dilution rate of $0.16 \mathrm{~d}^{-1}$ of $f / 2$ medium (Guillard 1975), a constant air supply, a light intensity of ca. $150 \mu \mathrm{E} \mathrm{m} \mathrm{m}^{-2} \mathrm{~s}^{-1}$, a 16:8 h light:dark regime and with the temperature held at $15^{\circ} \mathrm{C}$. All algal cultures were unialgal, but contained low concentrations of bacteria. O. marina was cultured using Rhodomonas sp. as food. Details of the culture conditions have been described by Klein Breteler \& Gonzalez (1986, 1988) and Klein Breteler \& Laan (1993).

Strombidium sulcatum (33 $\mu \mathrm{m}$ equivalent spherical diameter, ESD, $2240 \mathrm{pg} \mathrm{C}$ cell $^{-1}$ ), obtained from X. Mari (Station Zoologique, Villefranche sur Mer, France), was grown in batch culture on natural bacteria developing on wheat grains. From this culture, we inoculated 2 different 31 continuous cultures. In one, a bacteria medium was supplied to promote the growth 
of bacteria as food for $S$. sulcatum. The bacteria medium consisted of autoclaved filtered seawater containing $60 \mathrm{mg} \mathrm{l}^{-1}$ bactopeptone and $60 \mathrm{mg} \mathrm{l}^{-1}$ yeast extract (both from Difco) supplied at a rate of $0.25 \mathrm{~d}^{-1}$. The other culture was part of a 2-stage chemostat, in which Dunaliella sp. (6.7 $\mu \mathrm{m}$ ESD, 29 pg C cell $\left.{ }^{-1}\right)$ was continuously supplied to $S$. sulcatum at a dilution rate of $0.08 \mathrm{~d}^{-1}$. Dunaliella sp. was cultured in conditions similar to those of the other algae, except for a bottle volume of $0.5 \mathrm{l}$ and a dilution rate of $0.5 \mathrm{~d}^{-1}$. The cultures of $S$. sulcatum were aerated at a low rate of about 1 bubble per $2 \mathrm{~s}$ using compressed air, and stirred for $2 \mathrm{~s}$ every $80 \mathrm{~s}$ using a magnetic stirrer with an electronic time-control unit.

Concentrations and cell volumes of algae and protozoans were measured in samples from the continuous cultures using an Elzone electronic particle counter (Particle Data). For determination of carbon and lipid content, samples were filtered onto combusted Whatman GF/F filters and stored under $\mathrm{N}_{2}$ at $-50^{\circ} \mathrm{C}$. The carbon content was measured using a Carlo Elba CHN analyser. Since no separate cultures of the bacteria were available, the lipid composition of the bacteria could not be assessed under the present continuous culture conditions.

Lipid analysis. Samples were saponified by reflux (1 h) with $6 \mathrm{ml} 1 \mathrm{~N} \mathrm{KOH} /$ methanol (MeOH) solution. After acidifying the solution to $\mathrm{pH} 3$ with $2 \mathrm{~N} \mathrm{HCl}$ in water/MeOH $(1: 1, v / v)$, the solution was added in a separatory funnel with double-distilled water. Thereafter, the filters were extracted twice with doubledistilled water and subsequently with double-distilled water/MeOH $(1: 1, v / v)$, and 3 times with dichloromethane (DCM). All fractions were collected in the separation funnel. After separation of the DCM fraction, the remaining water/MeOH fraction was washed with DCM 2 more times, separating the DCM after each washing. Samples were dried on a rotavap, transferred into a sample jar and weighed. As an internal standard, 6,6-dideutero-3-methylheneicosane was added to quantify the amount of fatty acids. Extracts were methylated with diazomethane in DCM and eluted over a silica column with ethyl acetate.

For sterol analysis, an aliquot of the extract was dried under $\mathrm{N}_{2}$ and separated over $\mathrm{Al}_{2} \mathrm{O}_{3}$ using hexane/ $\operatorname{DCM}(1: 1 \mathrm{v} / \mathrm{v})$ and DCM/methanol $(1: 1 \mathrm{v} / \mathrm{v})$ to remove the methylated fatty acids from the remaining sample with sterols.

Immediately before gas chromatography (GC) and gas chromatography/mass spectrometry (GC/MS) analysis, samples were treated with bis(trimethylsilyl) trifluoracetamide to convert compounds containing free hydroxyl groups to their trimethylsilyl-ether (TMS) derivatives. GC analyses were performed using a Hewlett-Packard 5890 gas chromatograph with an on-column injector and a flame-ionisation detector. Samples were injected onto a fused silica capillary column (50 $\mathrm{m} \times 0.32 \mathrm{~mm}$ ) coated with CP Sil-5 (film thickness $0.12 \mu \mathrm{m})$. Helium was used as the carrier gas. Starting at $70^{\circ} \mathrm{C}$, the temperature was raised to $130^{\circ} \mathrm{C}$ at $20^{\circ} \mathrm{C} \mathrm{min}^{-1}$ and then at $4^{\circ} \mathrm{C} \mathrm{min}^{-1}$ to $320^{\circ} \mathrm{C}$. This temperature was maintained for $25 \mathrm{~min}$.

GC/MS analyses were performed using a HewlettPackard 6890 gas chromatograph with on-column injector, interfaced to a Hewlett-Packard 5973 mass spectrometer operated at $70 \mathrm{eV}$ with a mass range of $\mathrm{m} / \mathrm{z} 50-800$ and a measuring rate of 2 scans $\mathrm{s}^{-1}$. Samples were injected onto a fused silica capillary column (50 $\mathrm{m} \times 0.25 \mathrm{~mm}$ ) coated with CP Sil-8 (film thickness $0.25 \mu \mathrm{m})$. Helium was used as the carrier gas. Starting at $100^{\circ} \mathrm{C}$, the temperature was raised to $200^{\circ} \mathrm{C}$ at $15^{\circ} \mathrm{C}$ $\mathrm{min}^{-1}$ and then at $6^{\circ} \mathrm{C} \mathrm{min}^{-1}$ to $320^{\circ} \mathrm{C}$. This temperature was maintained for $25 \mathrm{~min}$.

Double-bond positions of fatty acids were determined by comparing retention times of the extracted compound with those of PUFA No. 1 and 2 standard mixtures (Matreya). For sterols, no standards were used. Since sterols with double bonds at Positions 7 and 8 give similar mass spectra, our identification of these sterols was tentative.

Experiments. The development times of the copepods were measured using an experimental set-up with 1.21 glass bottles, which were rotated at $1 \mathrm{rpm}$ using a rolling-table in a temperature-controlled room held at $15^{\circ} \mathrm{C}$ under dim light conditions. Young larvae and copepodites (250 to 490 specimens) of Temora longicornis or Pseudocalanus elongatus were taken from the broodstock, rinsed with double-filtered $(2 \mu \mathrm{m})$ seawater and incubated in $2 \mu \mathrm{m}$-filtered seawater with food. The stages of the larvae mainly varied from Nauplius IV to Copepodite II. Younger stages were not included, since they were considered unable to consume the large ciliates used as prey in our experiments (Berggreen et al. 1988). Incubation continued until most copepods were mature or dead. Food was supplied from the continuous cultures of Rhodomonas sp. or Strombidium sulcatum at a concentration of $\geq 300 \mu \mathrm{g}$ $\mathrm{C}^{-1}$. The experiments with $S$. sulcatum were carried out 3 times, using either bacteria or Dunaliella sp. as food for the ciliate. Every 1 or 2 d, $90 \%$ of the food medium was removed, using reverse flow filtration through a $50 \mu \mathrm{m}$ mesh, and replaced by new medium with food. Twice a week, the food concentration was measured using the Elzone particle counter. Sampling of copepods began $1 \mathrm{~d}$ after the start of the incubation, to allow for adaptation to the new food. The sampling was done 3 times per week to determine stage distribution and mortality, at the same time diluting the culture to keep the copepod biomass below a value equivalent to about 40 adult copepods $\mathrm{l}^{-1}$. Usually, 
30-50 copepods were collected per sampling time. Stage duration was calculated from the median development time (MDT) of successive stages. MDT is defined as the time when $50 \%$ of the population has not yet passed a certain stage. The statistical package S-plus was used to estimate MDT from gamma distribution functions, which adequately describe the cumulative stage distribution, as explained by Klein Breteler et al. (1994). Occasionally, when there was premature extermination of a population, MDT of the last stage was estimated by extrapolation of the gamma function. Extrapolation was applied only when at least $20 \%$ of the population had entered this stage, and these results are specifically indicated.
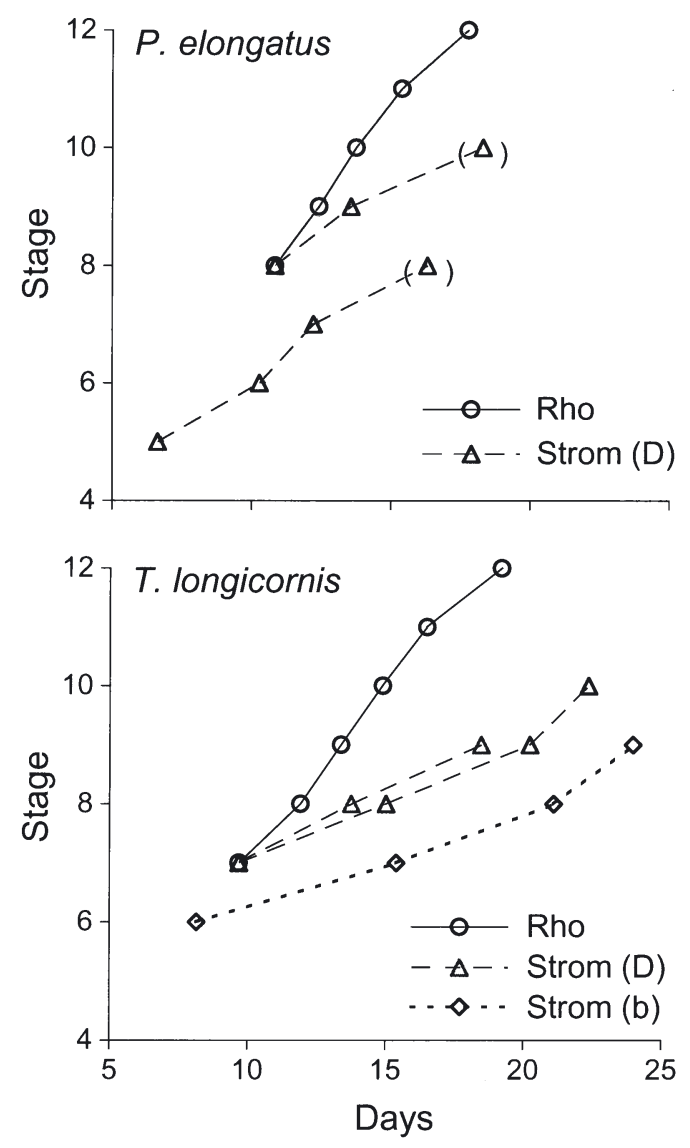

Fig. 1. Pseudocalanus elongatus and Temora longicornis. Cumulative median development times (MDT) of nauplii (Stages 4-6) and copepodites (Stages 7-12) in presence of the ciliate Strombidium sulcatum (Strom), cultured on bacteria (b) or Dunaliella sp. (D) and in control experiment with Rhodomonas sp. (Rho). Lines connect data of individual experiments; data points in parentheses are estimates obtained by extrapolation of gamma distribution functions. To synchronise different sets of data on same time scale, MDT of younger stages (not shown) were assumed to occur at $15^{\circ} \mathrm{C}$ and under optimal food conditions (Klein Breteler et al. 1994)
Instantaneous rates of mortality $\left(Z \mathrm{~d}^{-1}\right)$ were calculated according to $N_{\mathrm{t}}=N_{0} \mathrm{e}^{-\mathrm{zt}}$, where $N_{0}$ is the number of individuals $l^{-1}$ at Time 0 and $N_{\mathrm{t}}$ is the number of individuals $\mathrm{l}^{-1}$ at Time t. $N_{\mathrm{t}}$ was corrected for sampling mortality by multiplying the observed number of individuals by $V^{(\mathrm{n}-1)} /\left[\left(V-V_{1}\right) \cdot\left(V-V_{2}\right) \cdot \ldots \cdot\left(V-V_{(\mathrm{n}-1)}\right)\right]$, where $V$ is the volume of the experimental bottle, $V$ is the volume of the sample and $n$ is the rank number of the sample.

Grazing rates were measured using individuals collected from the above experiments after 1 and $3 \mathrm{~d}$ of incubation. The $1 \mathrm{~d}$ collections contained 24 to 72 copepodites, mainly $\mathrm{CI}$ and $\mathrm{CII}$, and the $3 \mathrm{~d}$ collections had 12 to 34 copepodites, mainly CII and C III (see Table 2). They were collected on a sieve and resuspended in 3 replicate $135 \mathrm{ml}$ bottles with seawater containing Strombidium sulcatum at an initial concentra-

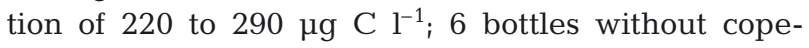
podites served as a control. The bottles were closed with a PTFE-lined screw cap, avoiding air bubbles, and were incubated on the rolling table under the same conditions as described for the development experiments. The concentrations of S. sulcatum were determined using the Elzone particle counter. In 3 control bottles, the abundance was determined immediately after preparation; the remaining 3 bottles together with the 3 bottles containing copepods were analysed after $24 \mathrm{~h}$ of incubation. At that time, the copepods were collected and enumerated according to their developmental stage. Grazing rates were calculated according to Frost (1972) and tested for differences using the 'bootstrap' method (Manly 1997).

The ash-free dry weight of the copepods was approximated after Klein Breteler et al. (1982) and Klein Breteler \& Gonzalez (1988), with correction for slight differences in size between the adults from the present and the former cultures. Carbon weight was calculated assuming $41 \%$ carbon content of the ash-free dry weight (Williams \& Robins 1982).

\section{RESULTS}

\section{Development}

There was a strong effect of food quality on the rate of copepod development, as reflected by the duration of the individual stages (Table 1) and the cumulative development time (Fig. 1). Differences among experiments were partly due to differences in age of the copepods at the start of the incubations (cf. levels of curves in Fig. 1). However, fast development occurred with the control food Rhodomonas sp., with Pseudocalanus elongatus and Temora longicornis developing through the copepodite stages in about $9 \mathrm{~d}$ (Fig. 1). In 
Table 1. Pseudocalanus elongatus and Temora longicornis. Duration (d) of developmental stages using Rhodomonas sp. (Rho) or the ciliate Strombidium sulcatum (Strom) as food source. S. sulcatum was grown using either bacteria (b) or Dunaliella sp. ( $\mathrm{D}_{i} 1$ and 2 indicate separate experiments). Numbers in italics: estimates obtained by extrapolation of gamma distribution functions. Stages 5 and 6: Naupliar

Stages 5 and 6; Stages 7-11: Copepodite Stages 1-5

\begin{tabular}{|c|c|c|c|c|c|c|c|}
\hline \multirow[t]{3}{*}{ Stage } & \multicolumn{3}{|c|}{ - P. elongatus - } & \multicolumn{4}{|c|}{$\longrightarrow$ T. longicornis } \\
\hline & \multirow[t]{2}{*}{ Rho } & \multicolumn{2}{|c|}{ Strom } & \multirow[t]{2}{*}{ Rho } & \multicolumn{3}{|c|}{ Strom } \\
\hline & & D1 & D2 & & $\mathrm{b}$ & D1 & D2 \\
\hline 5 & & 3.6 & & & & & \\
\hline 6 & & 1.9 & & & 7.2 & & 4.1 \\
\hline 7 & & 4.1 & & 2.2 & 5.7 & 5.3 & 4.7 \\
\hline 8 & 1.6 & & 2.7 & 1.5 & 2.9 & 5.2 & \\
\hline 9 & 1.3 & & 4.7 & 1.5 & & 2.1 & \\
\hline 10 & 1.6 & & & 1.6 & & & \\
\hline 11 & 2.4 & & & 2.7 & & & \\
\hline
\end{tabular}

contrast, when using Strombidium sulcatum as food, the rate of development was strongly reduced and most nauplii or young copepodites did not pass more than 2 successive stages. The reduced development seen with $S$. sulcatum did not seem to depend on the kind of food (viz. Dunaliella sp. or bacteria) fed to the ciliate, as shown in the experiment with T. longicornis (Fig.1).

\section{Mortality}

When fed Rhodomonas sp., the instantaneous rates of mortality of Temora longicornis and Pseudocalanus elongatus were low (5-12\% d $\mathrm{d}^{-1}$ ) and fairly constant, as shown by the regression line in Fig. 2. However, with Strombidium sulcatum as food source, the rate of mortality strongly increased during the experiment. The experiments were terminated due to the lack of copepods in the bottles with $S$. sulcatum.

\section{Grazing}

After $1 \mathrm{~d}$ of adaptation to Strombidium sulcatum, young copepodites (mainly CI and II) filtered ca. $1.5 \mathrm{ml}$ ind..$^{-1} \mathrm{~d}^{-1}$ (Table 2), equivalent to an average ingestion of 34 and $58 \%$ of the body carbon content in Pseudocalanus elongatus and Temora longicornis, respectively (Fig. 3). After another $2 \mathrm{~d}$ of feeding on S. sulcatum, the copepodites, albeit having developed to 1 higher stage on average (Table 2), cleared less water than initially, resulting in an average ingestion of only about $18 \%$ of their body carbon content (Fig. 3). The results from the $T$. longicornis experiments were to some extent rather variable, probably due to insuffi-
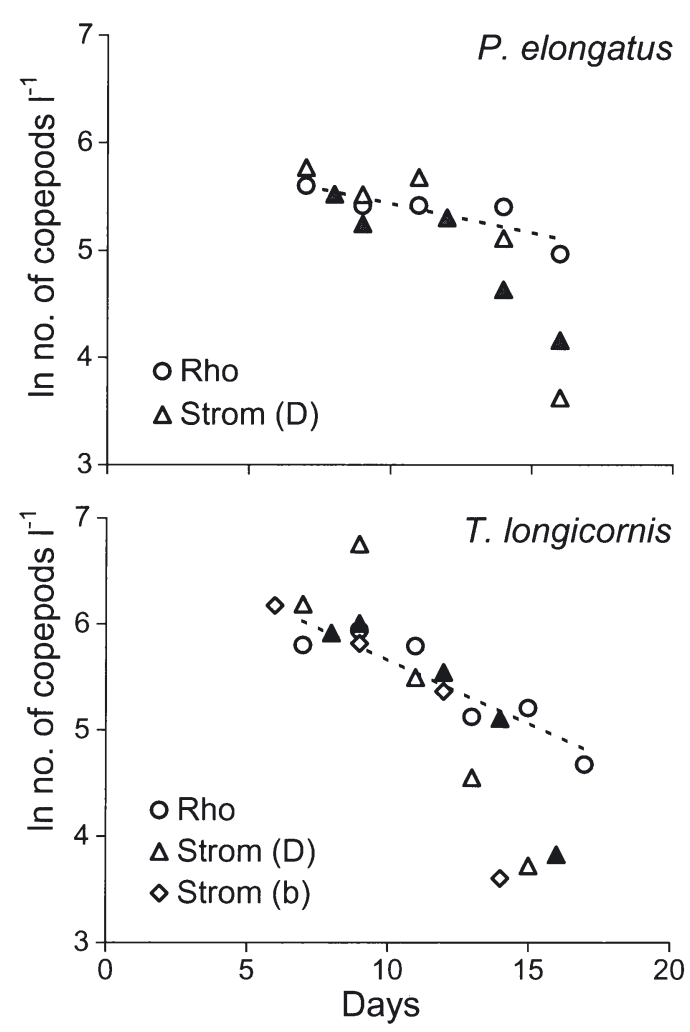

Fig. 2. Pseudocalanus elongatus and Temora longicornis. Concentration of young copepods in presence of the ciliate Strombidium sulcatum (Strom), cultured on bacteria (b) or Dunaliella sp. (D) and in control experiment with Rhodomonas sp. (Rho) including regression line. Open/closed symbols represent different experiments

Table 2. Pseudocalanus elongatus and Temora longicornis. Grazing rates of young copepodites after 1 and $3 \mathrm{~d}$ adaptation to Strombidium sulcatum. Results of triplicate $24 \mathrm{~h}$ experiments. n: no. of individuals; CR: clearance rate; Spec. ingest.: specific ingestion

\begin{tabular}{|c|c|c|c|c|c|}
\hline $\begin{array}{l}\text { Time } \\
\text { (d) }\end{array}$ & $\mathrm{n}$ & $\begin{array}{l}\text { Mean } \\
\text { stage }\end{array}$ & $\begin{array}{c}\text { Mean wt } \\
(\mu g \mathrm{C})\end{array}$ & $\begin{array}{c}\mathrm{CR} \\
\left(\mathrm{ml} \text { ind } .^{-1} \mathrm{~d}^{-1}\right)\end{array}$ & $\begin{array}{r}\text { Spec. } \\
\text { ingest. } \\
\left(\% d^{-1}\right)\end{array}$ \\
\hline \multicolumn{6}{|c|}{ Pseudocalanus elongatus } \\
\hline 1 & 35 & 7.3 & 1.26 & 1.32 & 31 \\
\hline 1 & 28 & 7.5 & 1.39 & 1.43 & 31 \\
\hline 1 & 24 & 7.3 & 1.27 & 1.67 & 39 \\
\hline 3 & 15 & 8.8 & 2.25 & 0.71 & 9 \\
\hline 3 & 18 & 8.3 & 1.86 & 1.29 & 19 \\
\hline 3 & 24 & 8.0 & 1.70 & 1.29 & 21 \\
\hline \multicolumn{6}{|c|}{ Temora longicornis } \\
\hline 1 & 72 & 7.2 & 0.51 & 1.66 & 56 \\
\hline 1 & 67 & 6.9 & 0.46 & 1.66 & 64 \\
\hline 1 & 54 & 7.3 & 0.55 & 1.53 & 54 \\
\hline 3 & 15 & 8.1 & 0.78 & 1.41 & 43 \\
\hline 3 & 12 & 7.9 & 0.68 & -0.29 & -11 \\
\hline 3 & 34 & 7.9 & 0.69 & 0.57 & 20 \\
\hline
\end{tabular}






Fig. 3. Pseudocalanus elongatus and Temora longicornis. Carbon-specific ingestion of young copepodites after 1 and $3 \mathrm{~d}$ adaptation to Strombidium sulcatum. Error bars: \pm SD $(\mathrm{n}=3)$

cient mixing of the fast swimming ciliates during preparation of the grazing bottles. The reduced grazing after $3 \mathrm{~d}$ of exposure to $S$. sulcatum was significant $(\mathrm{p}<0.05)$ in $P$. elongatus only.

\section{Behaviour and morphology}

After 5 d of feeding on Strombidium sulcatum, a significant number of young copepodites of both Temora longicornis and Pseudocalanus elongatus became inactive, with some of them showing abnormal morphology. In those individuals, the distal segments of the swimming feet were strongly swollen, along with the caudal rami of the urosome in a few of them.

\section{Lipid content and composition}

The total fatty acid content of Strombidium sulcatum was 7 times lower than that of Dunaliella sp. (Table 3). Their fatty acid compositions were more or less similar, particularly with regard to HUFAs, which were absent from both of them (Table 3). An accurate comparison is complicated by a high contribution (19\% on the basis of C) of Dunaliella sp. in the ciliate culture, while contamination was intensified by the high specific fatty acid content of the alga. After correction for Dunaliella $\mathrm{sp}$. in the ciliate culture, the proportions of fatty acids in $S$. sulcatum were not reliable and often not signifi- cantly different from zero. The dominant fatty acid in Dunaliella sp. was 18:3 13 , whereas in the ciliate C18: $1 \omega 7$ was most abundant. Of sterols, only low amounts of 24-methylcholest-7-en-3 $\beta$-ol $(\Delta 7 \mathrm{C} 28: 1)$ could be detected in Dunaliella sp., as well as traces of 3 other $\Delta 7$ sterols. In the samples of $S$. sulcatum, only traces of 2 of these $\Delta 7$ sterols were detectable, and these were probably due to Dunaliella sp. present in the samples. Most probably, therefore, the ciliate did not contain any sterol at all. Tetrahymanol or other sterol surrogates were also not detected in the samples from the ciliate.

Table 3. Dunaliella sp. and Strombidium sulcatum. Composition $(\%)$ and content $\left(\mu \mathrm{g} \mathrm{mg}{ }^{-1} \mathrm{C}\right)$ of fatty acids and sterols. Fatty acid values of $S$. sulcatum corrected for presence of Dunaliella sp., based on cell counts. tr: traces of sterols; (tr): traces include contamination due to Dunaliella sp.; SD: standard deviation within samples $(\mathrm{n}=3)$ due to analytical errors; $\mathrm{x}$ : impossible, ?: uncertain identification of double-bond positions from PUFA standard mixtures (among others due to different GC-column used); nd: not detectable; nq: not quantifiable due to coelution with hydroxy fatty acids (both insignificant amounts); ns: not significantly different from zero. Detection limit of sterols was ca. $0.3 \mu \mathrm{g} \mathrm{mg}^{-1} \mathrm{C}$

\begin{tabular}{|c|c|c|c|c|}
\hline \multirow[t]{2}{*}{ Fatty acid } & \multicolumn{2}{|c|}{ Dunaliella sp. } & \multicolumn{2}{|c|}{ S. sulcatum } \\
\hline & Mean \% & $\mathrm{SD}$ & Mean \% & $\mathrm{SD}$ \\
\hline C14:0 & 0.3 & 0.1 & 8.7 & 0.4 \\
\hline C15:0 & 0.7 & 0.2 & 4.9 & 0.5 \\
\hline C16:4 & 12.8 & 2.2 & $-10.4^{\mathrm{ns}}$ & 7.7 \\
\hline $\mathrm{C} 16: 3 \omega \mathrm{x}_{1}$ & 0.6 & 0.1 & $\mathrm{nq}$ & \\
\hline $\mathrm{C} 16: 3 \omega \mathrm{x}_{2}$ & 3.2 & 0.3 & $1.7^{\mathrm{ns}}$ & 1.6 \\
\hline $\mathrm{C} 16: 1 \omega \mathrm{x}_{1}$ & 0.2 & 0.0 & $0.6^{\mathrm{ns}}$ & 0.6 \\
\hline $\mathrm{C} 16: 1 \omega \mathrm{x}_{2}$ & 0.1 & 0.0 & 3.7 & 0.6 \\
\hline $\mathrm{C} 16: 1 \omega \mathrm{x}_{3}$ & 4.1 & 0.6 & -4.4 & 0.3 \\
\hline $\mathrm{C} 16: 1 \omega \mathrm{x}_{4}$ & 1.3 & 0.3 & 10.1 & 3.3 \\
\hline $\mathrm{C} 16: 1 \omega 7$ & 0.6 & 0.1 & 4.5 & 0.6 \\
\hline C16:0 & 23.8 & 4.4 & $13.8^{\mathrm{ns}}$ & 8.3 \\
\hline C18:4 $\omega 3$ & 1.0 & 0.2 & $3.7^{\mathrm{ns}}$ & 3.2 \\
\hline 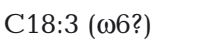 & 3.5 & 0.5 & $2.8^{\mathrm{ns}}$ & 2.5 \\
\hline C18:3 ( $\omega 3 ?)$ & 35.0 & 4.6 & $15.6^{\mathrm{ns}}$ & 22.3 \\
\hline $\mathrm{C} 18: 2 \omega \mathrm{x}$ & 1.4 & 0.1 & 5.4 & 0.8 \\
\hline C18:2 $\omega 6$ & 3.1 & 0.6 & $5.1^{\mathrm{ns}}$ & 2.4 \\
\hline $\mathrm{C} 18: 1 \omega 9$ & 5.7 & 1.0 & $-0.4^{\mathrm{ns}}$ & 0.8 \\
\hline $\mathrm{C} 18: 1 \omega 7$ & 2.2 & 0.3 & 31.4 & 0.8 \\
\hline C18:0 & 0.5 & 0.1 & 3.1 & 0.9 \\
\hline C20:5 & nd & & nd & \\
\hline \multirow[t]{2}{*}{$\mathrm{C} 22: 6$} & nd & & nd & \\
\hline & & $\mu g \mathrm{mg}^{-1} \mathrm{C}$ & $\mu \mathrm{g} \mathrm{mg}^{-1} \mathrm{C}$ & \\
\hline Total fatty acids & & 151.6 & 21.6 & \\
\hline \multicolumn{5}{|l|}{ Sterols } \\
\hline$\Delta 7 \mathrm{C} 28: 1$ & & 0.7 & (tr) & \\
\hline$\Delta 7,24(28) C 28: 2$ & & $\operatorname{tr}$ & nd & \\
\hline$\Delta 7,24(28) C 29: 2$ & & $\operatorname{tr}$ & nd & \\
\hline$\Delta 7 \mathrm{C} 29: 1$ & & $\operatorname{tr}$ & (tr) & \\
\hline
\end{tabular}




\section{DISCUSSION}

In this study, the ciliate Strombidium sulcatum was grown using low quality food deficient in HUFAs and $\Delta 5$ sterols, which are 'semi-essential' and essential compounds, respectively, for copepods. When feeding on $S$. sulcatum, the 2 species of copepods could not develop through more than a few stages. Their rate of development was low, they died at high rates, and reduced feeding was evident within a few days. Reduced motility and abnormal morphology unequivocally reflected the unsuitability of $S$. sulcatum as a food source. Probably this ciliate was not toxic for the copepods (see below). Biochemical analyses indicated that S. sulcatum did not upgrade the nutritional quality of food available to the copepods, in contrast to the heterotrophic dinoflagellate Oxyrrhis marina (Klein Breteler et al. 1999).

Sterols occurred in Dunaliella sp. at low concentration. They were not $\Delta 5$ sterols, but they were tentatively identified as $\Delta 7$ sterols (Table 3 ). Although $\Delta 7$ sterols are common to most Chlorophyceae (Volkman 1986, 2003), evidence for their digestion by copepods is contradictory (Prahl et al. 1984, Harvey et al. 1987). Lack of growth (Koski et al. 1998, Klein Breteler et al. 1999 and this study) and reduced egg production (Ederington et al. 1995) of copepods feeding on organisms with only $\Delta 7$ sterols also support the idea that $\Delta 7$ sterols are not efficiently used by copepods. We found no evidence for the presence of sterols in Strombidium sulcatum, an observation which has been made previously in 2 other species of bacterivorous ciliates by Ederington et al. (1995) and Harvey et al. (1997). Even the small amounts of $\Delta 7$ sterols detected in the Dunaliella sp. food were hardly or not found in S. sulcatum. This indicates that the ciliate neither produced nor transferred sterols to higher trophic levels. Since copepods have an essential requirement for sterols, the lack of sterols was likely to be the primary cause of the reduced performance of the copepods feeding on the ciliates. In future studies, a new technique developed recently to supplement sterols to food algae (VonElert et al. 2003), may make it possible to prove sterol limitation due to ciliate food.

Most animals, including marine calanoid copepods, have an absolute requirement for $\omega 3$-PUFAs in their food (Brett \& Müller-Navarra 1997). Dunaliella sp. is a rich source of linolenic acid (18:3 03$)$, which could cover the $\omega 3$-PUFA requirement of copepods. In our experiments, from the biochemical composition of Strombidium sulcatum it seems that this ciliate transferred $\omega 3$-PUFAs from the alga to the copepods. In copepods, further chain elongation and desaturation of linolenic acid into HUFAs have been shown in harpacticoids (Norsker \& Støttrup 1994, Nanton \& Castell 1999) as well as in the marine calanoid Para- calanus parvus (Moreno et al. 1979). However, although a number of metazoans are able to convert HUFAs from linolenic acid, the rate of this process appears to be too slow for an optimal growth rate (Brett \& Müller-Navarra 1997). Hence, limitation due to HUFAs would result in a reduced rate of development, as shown in Daphnia galeata feeding on Scenedesmus obliquus (VonElert 2002). Using cyanobacterial food deficient in PUFAs as well as sterols (Volkman 2003), VonElert \& Wolffrom (2001) showed that supplementation with PUFAs did not enhance the rate of growth of D. galeata, whereas recent experiments showed that sterol supplementation did enhance growth of the cladoceran (VonElert et al. 2003). Certainly, the complete cessation of copepod growth observed in Temora longicornis and Pseudocalanus elongatus fed S. sulcatum cannot be explained by the rate-limiting conversion of EPA from linolenic acid, but rather suggests that growth was halted due to the lack of compounds that copepods cannot synthesise, such as sterols.

In the experiments using Dunaliella sp. as food for Strombidium sulcatum, bacteria occurring, albeit at low abundance, in the culture of Dunaliella sp. were a potential food source for the ciliate as well. The high abundance of 18:1 107 in the ciliate may point to a bacterial origin (Brown et al. 1996). However, regarding the low total amount of fatty acids in S. sulcatum, it is still possible that the ciliate obtained all C18:107 from Dunaliella sp. We did not observe branched, oddnumbered fatty acids, characteristic of bacteria, in the ciliates. Therefore, it seems that bacteria did not play a significant role as food source for S. sulcatum in our experiments with Dunaliella sp. In contrast, Dunaliella sp. was a significant food source: from the flow rate and the cell abundance in the 2-stage continuous culture we calculated a grazing rate of 3 algal cells ciliate $^{-1} \mathrm{~h}^{-1}$, which is a daily consumption equal to ca. $93 \%$ of the ciliate's carbon content.

Since bacteria generally do not produce PUFAs or sterols, probably the same deficiency in sterols and/or HUFAs explains the low food quality of Strombidium sulcatum when it was feeding on bacteria. Nevertheless, Bonnet \& Carlotti (2001), using a diet of S. sulcatum feeding on bacteria, observed growth and egg production of Centropages typicus. We cannot explain the difference between our results and theirs, but possibly ergosterol and fatty acids from yeast and peptone present in the bacterial medium of Bonnet \& Carlotti became available to C. typicus. Also in other crustaceans, Daphnia spp. (Tezuka 1974, DeBiase et al. 1990) and several species of cyclopoid copepods (Abdullahi 1992), grown using bacterivorous ciliates as food, the requirements for essential lipids may have been met by contamination from the bacterial media. The medium used by Tezuka (1974) was not specified, 
whereas the other authors used cereal grasses (DeBiase et al. 1990) or hay infusions (Abdullahi 1992) to grow bacteria together with the ciliates. Other potential sources of sterols include agar, latex, filters, yeasts and fungi (J. K. Volkman pers. comm.). Unfortunately, no biochemical analyses were performed in the above studies, which makes it impossible to exclude transfer of essential lipids from the media.

Juvenile copepods feeding on Strombidium sulcatum showed abnormal morphology, which we have never observed before in studies on food availability (Klein Breteler et al. 1982, 1995, Klein Breteler \& Gonzalez 1986, 1988, Klein Breteler \& Schogt 1994). Therefore, shortage of food does not seem to explain the swollen appendages observed after feeding on S. sulcatum. In Temora stylifera, morphological aberrations due to toxic hydrocarbons present in diatom food have been reported (Carotenuto et al. 2002). Swollen extremities seem to indicate a lack of rigidity of the exoskeleton, such as that observed in insects due to microviridine, and in cladocerans due to an unknown bioactive compound with a molecular weight corresponding to microviridine that occurred in a cyanobacterial diet (Kaebernick et al. 2001). However, strong evidence against the possibility of toxic or bioactive compounds in S. sulcatum was provided by a test using a mixture of Rhodomonas sp. and $S$. sulcatum as food for copepods. In this mixture, Nauplii IV and V of $T$. longicornis significantly grazed on both the algae and the ciliates (M. Koski unpubl.). At the same time, they developed well at a rate comparable to the rate observed with the Rhodomonas sp. diet alone (Fig. 1). Since this rules out toxicity as an explanation, the lack of sterols in the ciliate diet remains as the primary cause for a reduced rigidity of the exoskeleton. Sterols are required for cellular architecture by reinforcing cell walls. They are precursors of steroid hormones and, therefore, play a role in the moulting process. Moreover, there is evidence that sterol-protein complexes are involved in tanning and hardening of crustacean cuticles (Dennell 1960). Therefore, a disturbed moulting and cuticle physiology due to a sterol deficiency is probably the cause of the morphological abnormalities we observed.

Studies on biochemical synthesis and transfer of lipids by ciliates would profit from the availability of algal species deficient in either sterols or HUFAs, but not in both, as was the case in our study with Dunaliella sp. To date, we have also attempted to grow Strombidium sulcatum on Synechococcus sp., Isochrysis galbana and Rhodomonas sp., of which the latter 2 species contain sterols as well as HUFAs and are known for their good quality as food for copepods. Unexpectedly, Strombidium sulcatum did not grow on the cyanobacterium nor on the 2 algal species, although the algae are also naked flagellates of similar motility and of a size smaller than or similar to Dunaliella sp. It is possible that $S$. sulcatum did not feed on these algae, which would account for the low growth rates. S. sulcatum also did not consume the slightly larger Hymenomonas elongata and Thalassiosira weissflogii (Bonnet \& Carlotti 2001). Recently, S. sulcatum has been grown using the flagellate Marsupiomonas pelliculata as food (Broglio et al. 2003). Another, larger species, Strombidium sp., only grew on Pavlova (Monochrysis) lutheri, but not on Isochrysis sp. and, surprisingly, also not on Dunaliella sp. (Scott 1985). Apart from selective food ingestion, differences in the nutritional demands of Strombidium species may underlie their specific growth responses to different diets.

Species of freshwater ciliates are known for their different requirements of lipids for growth (Dewey 1967, Anderson 1988, Sleigh 1989). The present study suggests that Strombidium sulcatum does not require HUFAs or sterols to prosper. Like most ciliates (Ederington et al. 1995, Harvey et al. 1997), S. sulcatum neither needs these compounds in its food, nor does it have a biochemical pathway to synthesise them de novo or by conversion from other lipids. Exceptions to this are the scuticociliate Parauronema acutum (Sul \& Erwin 1997) and the hypotrich Euplotes crassus (Zhukova \& Kharlamenko 1999), which synthesise HUFAs, although at a low rate. Euplotes sp. is also the only ciliate known to produce a sterol (Harvey \& McManus 1991). However, sterols are indispensable in maintaining cell membrane fluidity (Ourisson et al. 1987), and, hence they occur in virtually all higher organisms. In bacteria they are functionally replaced by hopanoids. In ciliates, different surrogates of sterols have been found. Scuticociliates and Tetrahymena pyriformis (both in the class Oligohymenophora) contain tetrahymanol and hopanoids as sterol surrogates, but in Euplotes sp. (class Nassophorea) and in the heterotrich Fabrea salina, tetrahymanol does not occur (Harvey \& McManus 1991, Harvey et al. 1997). We also did not detect tetrahymanol in the oligotrich $S$. sulcatum (class Polyhymenophora). Possibly this ciliate uses hopanoids as a sterol surrogate which, however, may have remained undetected due to their low solubility and difficulty to extract (Ourisson \& Rohmer 1992).

In summary, our study supports that marine ciliates are generally incapable of synthesising sterols and HUFAs. Deficiency of sterols seems to make bacterivorous ciliates unsuitable as a single food for copepods. The food selection habits and/or the nutritional demands of ciliates seem to be highly specific, and both constitute gaps in our knowledge that need to be filled to understand their biochemical capabilities and intermediary role between the microbial food web and higher trophic levels in the food chain. 
Acknowledgements. We are grateful to Dr. J. van der Meer for calculation of the Gamma distribution functions. Thanks are due to Dr. G. J. Herndl for critically reading the manuscript. An anonymous reviewer is thanked for detailed improvements of the text.

\section{LITERATURE CITED}

Abdullahi BA (1992) Effects of diet on growth and development of three species of cyclopoid copepods. Hydrobiologia 232:233-241

Anderson OR (1988) Comparative protozoology. SpringerVerlag, Berlin

Barclay WR, Meager KM, Abril JR (1994) Heterotrophic production of long chain omega-3 fatty acids utilizing algae and algae-like microorganisms. J Appl Phycol 6:123-129

Berggreen U, Hansen B, Kiørboe T (1988) Food size spectra, ingestion and growth of the copepod Acartia tonsa during development: implications for determination of copepod production. Mar Biol 99:341-352

Bonnet D, Carlotti F (2001) Development and egg production in Centropages typicus (Copepoda: Calanoida) fed different food types: a laboratory study. Mar Ecol Prog Ser 224: 133-148

Brett MT, Müller-Navarra DC (1997) The role of highly unsaturated fatty acids in aquatic food web processes. Freshw Biol 38:483-499

Broglio E, Jonasdottir SH, Calbet A, Jakobsen HH, Saiz E (2003) Effect of heterotrophic versus autotrophic food on feeding and reproduction of the calanoid copepod Acartia tonsa: relationship with prey fatty acid composition. Aquat Microb Ecol 31:261-278

Brown MR, Barrett SM, Volkman JK, Nearhos SP, Nell JA, Allan GL (1996) Biochemical composition of new yeasts and bacteria evaluated as food for bivalve aquaculture. Aquaculture 143:341-360

Brown M, Jeffrey S, Volkman J, Dunstan G (1997) Nutritional properties of microalgae for mariculture. Aquaculture 151: 315-331

Carotenuto Y, Ianora A, Buttino I, Romano G, Miralto A (2002) Is postembryonic development in the copepod Temora stylifera negatively affected by diatom diets? J Exp Mar Biol Ecol 276:49-66

DeBiase AE, Sanders RW, Porter KG (1990) Relative nutritional value of ciliate protozoa and algae as food for Daphnia. Microb Ecol 19:199-210

Dennell R (1960) Integument and exoskeleton. In: Waterman TH (ed) The physiology of Crustacea. I. Metabolism and growth. Academic Press, New York, p 449-472

Dewey VC (1967) Lipid composition, nutrition and metabolism. In: Florkin M, Scheer BT (eds) Chemical zoology. Academic Press, New York, p 161-274

Ederington MC, McManus GB, Harvey HR (1995) Trophic transfer of fatty acids, sterols and a triterpenoid alcohol between bacteria, a ciliate, and the copepod Acartia tonsa. Limnol Oceanogr 40:860-867

Frost BW (1972) Effects of size and concentration of food particles on the feeding behavior of the marine planktonic copepod Calanus pacificus. Limnol Oceanogr 17:805-815

Goad LJ (1981) Sterol biosynthesis and metabolism in marine invertebrates. Pure Appl Chem 51:837-852

Guillard RRL (1975) Culture of phytoplankton for feeding marine invertebrates. In: Smith WL, Chanley MH (eds) Culture of marine invertebrate animals. Plenum Press, New York, p 29-60

Harrington GW, Holz GG Jr (1968) The monoenoic and docosahexaenoic fatty acids of a heterotrophic dinoflagellate. Biochim Biophys Acta 164:422-427

Harvey RH, McManus GB (1991) Marine ciliates as a widespread source of tetrahymanol and hopan-3 $\beta$-ol in sediments. Geochim Cosmochim Acta 55:3387-3390

Harvey HR, Eglinton G, O'Hara SCM, Corner EDS (1987) Biotransformation and assimilation of dietary lipids by Calanus feeding on a dinoflagellate. Geochim Cosmochim Acta 51:3031-3040

Harvey HR, Ederington MC, McManus GB (1997) Lipid composition of the marine ciliates Pleuronema sp. and Fabrea salina: shifts in response to changes in diet. J Eukaryot Microbiol 44:189-193

Kaebernick M, Rohrlack T, Christoffersen K, Neilan BA (2001) A spontaneous mutant of microcystin biosynthesis: genetic characterization and effect on Daphnia. Environ Microbiol 3:669-679

Kaneshiro ES, Beischel LS, Merkel SJ, Rhoads DE (1979) The fatty acid composition of Paramecium aurelia cells and cilia: changes with culture age. J Protozool 26:147-158

Klein Breteler WCM, Gonzalez SR (1986) Culture and development of Temora longicornis (Copepoda, Calanoida) at different conditions of temperature and food. Syllogeus 58:71-84

Klein Breteler WCM, Gonzalez SR (1988) Influence of temperature and food concentration on body size, weight and lipid content of two calanoid copepod species. Hydrobiol 167/168:201-210

Klein Breteler WCM, Laan M (1993) An apparatus for automatic counting and controlling density of pelagic food particles in cultures of marine organisms. Mar Biol 116: 169-174

Klein Breteler WCM, Schogt N (1994) Development of Acartia clausi (Copepoda, Calanoida) cultured at different conditions of temperature and food. Hydrobiologia 292/293: 469-479

Klein Breteler WCM, Fransz HG, Gonzalez SR (1982) Growth and development of four calanoid copepod species under experimental and natural conditions. Neth J Sea Res 16: 195-207

Klein Breteler WCM, Schogt N, Van der Meer J (1994) The duration of copepod life stages estimated from stagefrequency data. J Plankton Res 16:1039-1057

Klein Breteler WCM, Gonzalez SR, Schogt N (1995) Development of Pseudocalanus elongatus (Copepoda, Calanoida) cultured at different temperature and food conditions. Mar Ecol Prog Ser 119:99-110

Klein Breteler WCM, Schogt N, Baas M, Schouten S, Kraay GW (1999) Trophic upgrading of food quality by protozoans enhancing copepod growth: role of essential lipids. Mar Biol 135:191-198

Koski M, Klein Breteler W, Schogt N (1998) Effect of food quality on rate of growth and development of the pelagic copepod Pseudocalanus elongatus (Copepoda, Calanoida). Mar Ecol Prog Ser 170:169-187

Manly BFJ (1997) Randomization, bootstrap and Monte Carlo methods in biology. Chapman \& Hall, London

Moreno VJ, Moreno JEAd, Brenner RR (1979) Fatty acid metabolism in the calanoid copepod Paracalanus parvus. 1. Polyunsaturated fatty acids. Lipids 14:313-317

Nanton DA, Castell JD (1999) The effects of temperature and dietary fatty acids on the fatty acid composition of harpacticoid copepods, for use as a live food for marine fish larvae. Aquaculture 175:167-181

Norsker NH, Støttrup JG (1994) The importance of dietary HUFAs for fecundity and HUFA content in the harpacticoid, Tisbe holothuriae Humes. Aquaculture 125:1-2 
Ourisson G, Rohmer M (1992) Hopanoids. 2. Biohopanoids: a novel class of bacterial lipids. Accounts Chem Res 25: 403-408

Ourisson G, Rohmer M, Poralla K (1987) Prokaryotic hopanoids and other polyterpenoid sterol surrogates. Annu Rev Microbiol 41:301-333

Phillips NW (1984) Role of different microbes and substrates as potential suppliers of specific, essential nutrients to marine detritivores. Bull Mar Sci 35:283-298

Prahl FG, Eglinton G, Corner EDS, O'Hara SCM, Forsberg TEV (1984) Changes in plant lipids during passage through the gut of Calanus. J Mar Biol Assoc UK 64: 317-334

Sanders RW, Wickham SA (1993) Planktonic protozoa and metazoa: predation, food quality and population control. Mar Microb Food Webs 7:197-223

Sargent JR, Parkes RJ, Mueller-Harvey J, Henderson RJ (1987) Lipid biomarkers in marine ecology. In: Sleigh MA (ed) Microbes in the sea. Ellis Horwood, Chichester, p 119-138

Scott JM (1985) The feeding rates and efficiencies of a marine ciliate, Strombidium sp., grown under chemostat steadystate conditions. J Exp Mar Biol Ecol 90:81-95

Sleigh M (1989) Protozoa and other protists. Edward Arnold, London

Sul DG, Erwin JA (1997) The membrane lipids of the marine ciliated protozoan Parauronema acutum. Biochim Biophys Acta 1345:162-171

Tang KW, Jakobsen HH, Visser AW (2001) Phaeocystis globosa (Prymnesiophyceae) and the planktonic food web:

Editorial responsibility: Otto Kinne (Editor),

Oldendorf/Luhe, Germany feeding, growth, and trophic interactions among grazers. Limnol Oceanogr 46:1860-1870

Tezuka Y (1974) An experimental study on the food chain among bacteria, Paramecium and Daphnia. Int Rev Gesamten Hydrobiol 59:31-37

Volkman JK (1986) A review of sterol markers for marine and terrigenous organic matter. Org Geochem 9:83-99

Volkman JK (2003) Sterols in microorganisms. Appl Microbiol Biotechnol 60:495-506

VonElert E (2002) Determination of limiting polyunsaturated fatty acids in Daphnia galeata using a new method to enrich food algae with single fatty acids. Limnol Oceanogr 47:1764-1773

VonElert E, Wolffrom T (2001) Supplementation of cyanobacterial food with polyunsaturated fatty acids does not improve growth of Daphnia. Limnol Oceanogr 46: 1552-1558

VonElert E, Martin-Creuzburg D, Le Coz JR (2003) Absence of sterols constrains carbon transfer between cyanobacteria and a freshwater herbivore (Daphnia galeata). Proc R Soc Lond Ser B Biol Sci 270:1209-1214

Williams R, Robins DB (1982) Effects of preservation on wet weight, dry weight, nitrogen and carbon contents of Calanus helgolandicus. Mar Biol 71:271-281

Wood BJB (1988) Lipids of algae and protozoa. In: Ratledge C, Wilkinson SG (eds) Microbal lipids. Academic Press, London, p 806-867

Zhukova NV, Kharlamenko VI (1999) Sources of essential fatty acids in the marine microbial loop. Aquat Microb Ecol 17:153-157

Submitted: May 5, 2003; Accepted: February 24, 2004

Proofs received from author(s): June 9, 2004 